\title{
Normal Values for Cerebrospinal Fluid in Neonates: A Systematic Review
}

\author{
Petra Zimmermann ${ }^{a, b}, c, d \quad$ Nigel Curtis $c$, d, e \\ ${ }^{a}$ Department of Paediatrics, Fribourg Hospital HFR, Fribourg, Switzerland; ${ }^{b}$ Faculty of Science and Medicine, \\ University of Fribourg, Fribourg, Switzerland; 'Department of Paediatrics, The University of Melbourne, Parkville, \\ VIC, Australia; 'Infectious Diseases Research Group, Murdoch Children's Research Institute, Parkville, VIC, Australia; \\ eInfectious Diseases Unit, The Royal Children's Hospital Melbourne, Parkville, VIC, Australia
}

\author{
Keywords \\ Meningitis - Cerebrospinal fluid - Cell count - White cells . \\ White blood cell · Leucocytes - Lymphocytes - Neutrophils . \\ Protein.Glucose · Lumbar puncture
}

\begin{abstract}
Background: The diagnosis of neonatal meningitis often rests on microscopic and biochemical findings in the cerebrospinal fluid (CSF). There is ongoing uncertainty about age-related normal values for CSF findings in neonates, and many previous studies have included infants in whom antibiotics were administered before lumbar puncture or in whom viral meningitis was not excluded. Methods: A systematic search was done using MEDLINE and EMBASE to identify original studies which investigated CSF normal values in either healthy neonates or febrile neonates in whom bacterial and viral meningitis were reliably excluded. $\boldsymbol{R e}-$ sults: We identified seven studies investigating 270 term and 96 preterm neonates. There were minimal differences between preterm and term neonates in the CSF white blood cell (WBC) count and glucose concentration. In contrast, the CSF neutrophil count and protein concentration were influenced by gestational and chronological age. In the four studies that reported individual patient data, in $95 \%$ of cases the CSF WBC count was $<12$ cells $/ \mu \mathrm{L}$ in preterm and $<10$ cells $/ \mu \mathrm{L}$ in term neonates, the neutrophil count was $<16$ and 8 cells/ $\mu \mathrm{L}$, and the protein concentration was $<210$ and $110 \mathrm{mg} / \mathrm{dL}$,
\end{abstract}

(C) 2021 The Author(s)

Published by S. Karger AG, Basel

This is an Open Access article licensed under the Creative Commons Attribution-NonCommercial-4.0 International License (CC BY-NC) (http://www.karger.com/Services/OpenAccessLicense), applicable to the online version of the article only. Usage and distribution for commercial purposes requires written permission. respectively. Conclusion: The normal range for CSF parameters in neonates is different to that in older infants, and some parameters are influenced by gestational and chronological age. CSF parameters alone are not sufficiently reliable to exclude meningitis.

(C) 2021 The Author(s).

Published by S. Karger AG, Basel

\section{Introduction}

The gold standard for diagnosing bacterial meningitis is the isolation of pathogens in the cerebrospinal fluid (CSF). However, the diagnosis often depends on the microscopic and biochemical findings in the CSF, including a Gram stain, white blood cell (WBC) count, and differential, together with protein and glucose concentrations. This is also the case when antibiotics are administered before lumbar puncture (LP). Even with all these parameters available, it is often difficult to diagnose meningitis and to differentiate bacterial from aseptic meningitis. Furthermore, there is ongoing uncertainty about age-related normal values of CSF parameters, especially in neonates. The blood-brain barrier in neonates differs to that in older children [1], and normal values in infants, particularly neonates, are therefore different from those in older children. Age-related normal values of CSF findings have previously been reviewed [2]. However, many studies included children in whom antibiotics were given be- 
Fig. 1. Selection of studies. LP, lumbar puncture.

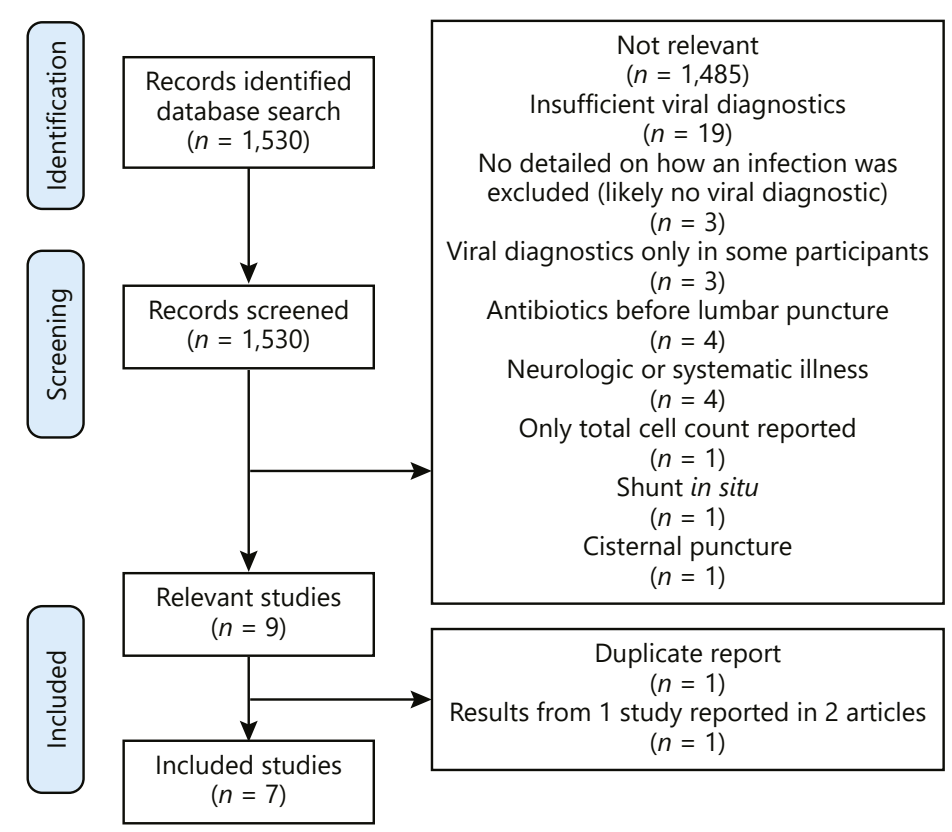

fore LP or in whom viral meningitis was not excluded reliably [3-7]. Also, additional studies have been published in recent years. In this systematic review, we summarize studies which investigated CSF parameters in healthy neonates, including those born preterm, using stringent inclusion criteria to define normal neonatal CSF values more reliably.

\section{Systematic Review Methods}

To identify studies which investigated CSF normal values in healthy neonates or febrile neonates in whom meningitis was reliably excluded, MEDLINE (1946 to present) and EMBASE (1947 to present) were searched in August 2020 using the Ovid interface with the following search terms: (cerebrospinal fluid [analysis, chemistry, cytology, diagnosis, microbiology] OR meningitis [cerebrospinal fluid, diagnosis] OR spinal puncture OR lumbar puncture) AND (infant OR neonat* OR newborn) without any language limitations. Exclusion criteria were studies that: (i) did not include molecular diagnostics to exclude enterovirus infection; (ii) included neonates in whom antibiotics were administered before LP; (iii) included neonates with underlying disease; (iv) included neonates with CSF shunts, and (v) included neonates in whom CSF was collected by a route other than LP. References of retrieved articles were hand-searched for additional publications.

The following variables were extracted from the included studies: year of study, country, study design, number, and characteris- tics of participants and key findings including CSF WBC and CSF glucose and protein concentrations. Statistical analyses and graphs were done using $\mathrm{R}$ version 3.4.3. The Mann-Whitney $\mathrm{U}$ test was used to compare values between groups.

\section{Systematic Review Results}

Our search identified 1,530 studies. Of these, nine fulfilled the inclusion criteria (Fig. 1) [8-16]. No additional relevant studies were identified by hand searching of references. Two studies reported the same group of neonates, one the cell counts and the other the biochemical findings, considered hereon in as one study $[8,9]$. Two other studies reported the same findings in different languages [10, 11]. Therefore, 7 studies were included in the review, all of which were case series. These reported the results from 270 term (in 5 studies) [12-16] and 96 preterm infants (in 2 cohorts) [8-11]. The number of participants in each study ranged from 19 to 108 (mean 52, median 43). The studies were done in Brazil 4, USA 2, and Spain 1. The results of the studies are summarized in Table 1.

\section{WBC Count}

The two studies that investigated the CSF WBC count in preterm neonates, reported a range from 0 to 

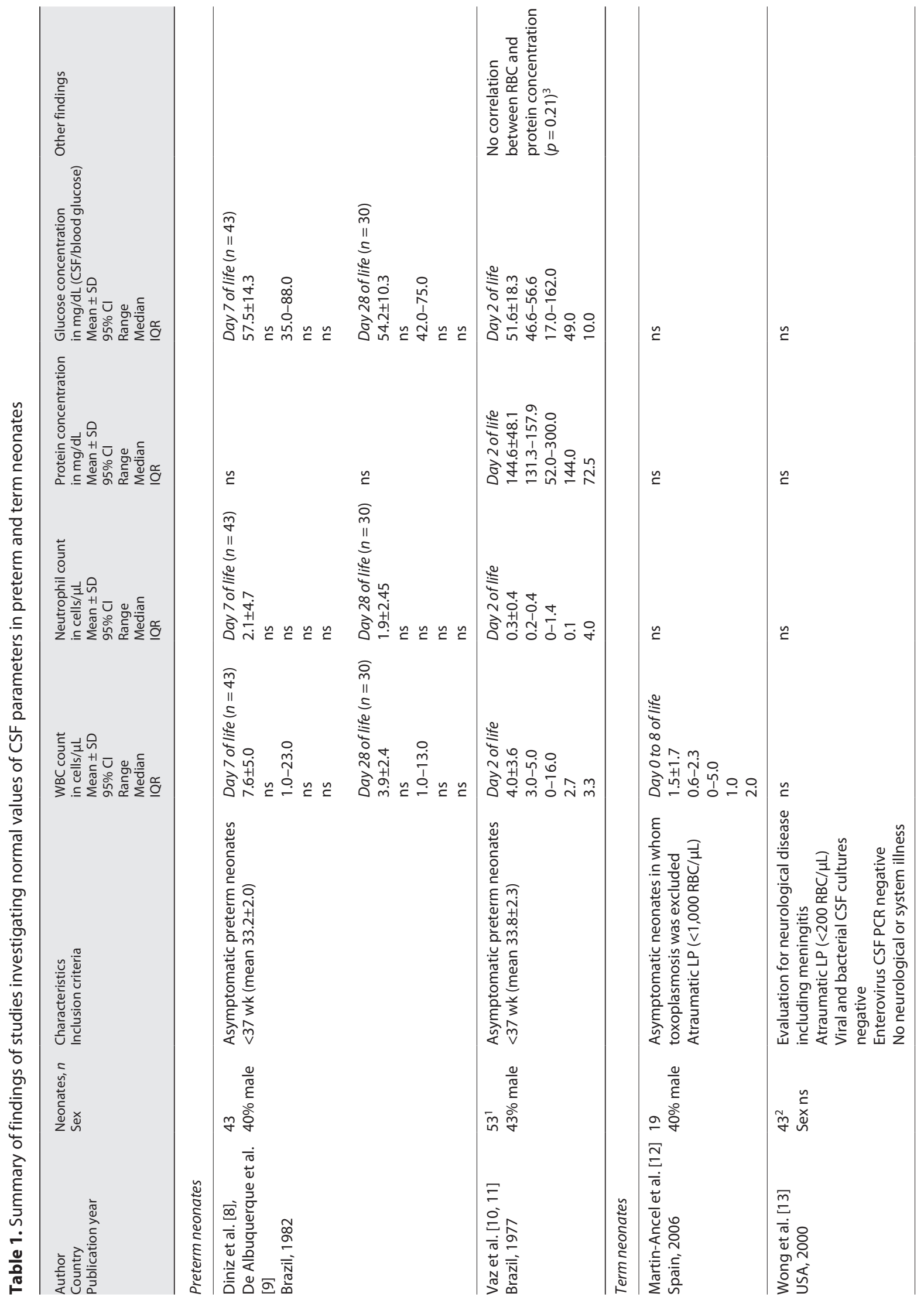


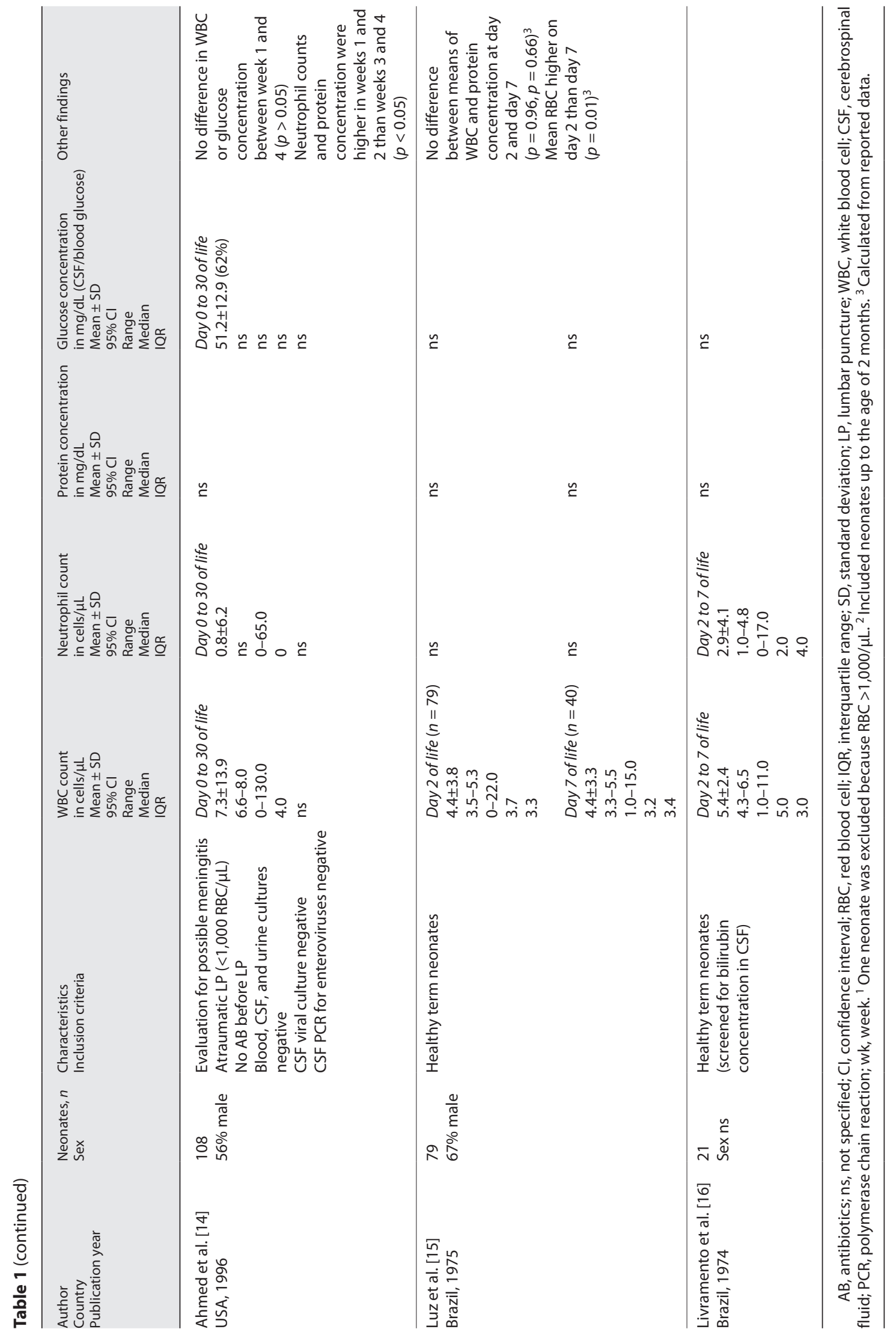


Table 2. Summary of findings from the 4 of 7 studies investigating normal CSF values that specified individual values

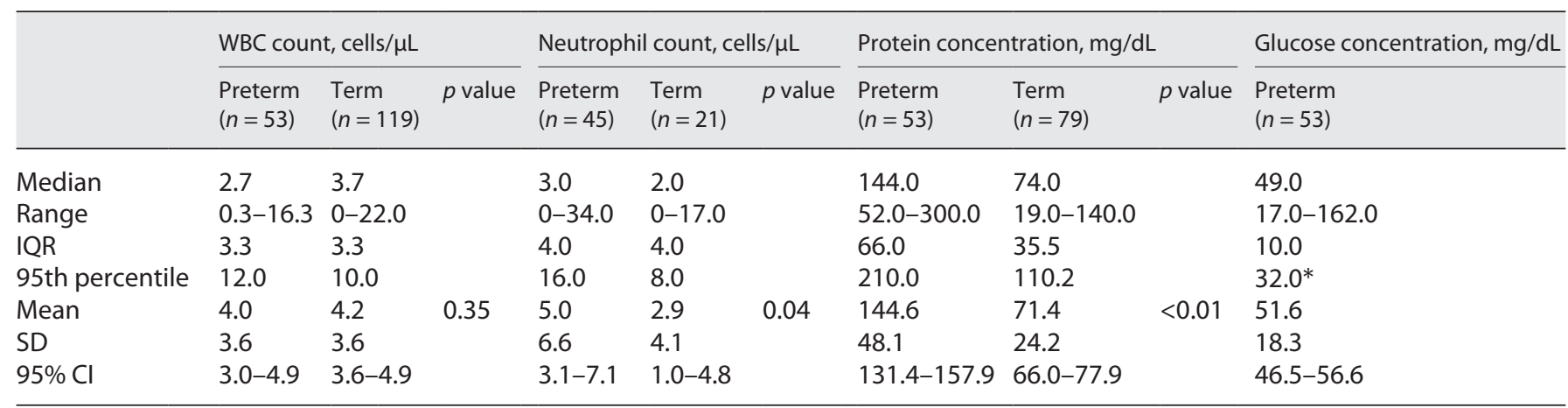

$\mathrm{Cl}$, confidence interval; IQR, interquartile range; SD, standard deviation; WBC, white blood cell; CSF, cerebrospinal fluid. *5th percentile.

23.0 cells $/ \mu \mathrm{L}$ in the first week of life and from 1.0 to 13.0 cells $/ \mu \mathrm{L}$ at 1 month of age $[8,10]$. In one of the studies in preterm neonates, the CSF WBC count decreased from a mean of 7.6 (range 1.0-23.0) cells/ $\mu \mathrm{L}$ on day 7 of life to a mean of 3.9 (range 1.0-13.0) cells $/ \mu \mathrm{L}$ on day 28 of life [8]. The other study in preterm neonates reported a mean of 4.0 (range $0-16.0$ ) cells $/ \mu \mathrm{L}$ on day 2 of life [10].

Four studies reported the CSF WBC count in term infants. This ranged from 0 to 130.0 cells $/ \mu \mathrm{L}$ (though this upper value was deemed potentially indicative of meningitis by the authors) with means ranging from 1.5 to 7.3 cells/ $\mu \mathrm{L}[12,14-16]$. There was no difference between the CSF WBC count on day 2 and $7(p=0.96)$ [15]. In one study there were 2 term neonates with very high WBCs (130.0 and 62.0 cells/ $\mu \mathrm{L}$ ) [14]. Apart from these two neonates, the highest $\mathrm{WBC}$ count in a term neonate was 28.0 cells/ $\mu \mathrm{L}[14]$.

Table 2 and Figure 2 summarize the CSF WBC count for individual neonates in the four studies in which these data were reported $[10,12,15,16]$. The mean CSF WBC count was 4.0 cells $/ \mu \mathrm{L}$ in preterm $(n=53)$ (standard deviation [SD 3.6], median 2.7, interquartile range [IQR] 3.3 , range $0.3-16.3)$ and 4.2 cells/ $\mu \mathrm{L}$ in term $(n=119)$ neonates $(3.6,3.7,3.3,0-22.0)(p=0.35)$. The 95 th percentile for CSF WBC count was 12.0 cells/ $\mu \mathrm{L}$ in preterm and 10.0 cells $/ \mu \mathrm{L}$ in term neonates.

\section{Neutrophil Count}

Four studies (two in preterm neonates) reported the neutrophil count in CSF $[8,10,14,16]$. In 96 preterm neonates $[8,10]$, the mean neutrophil count was 0.3 and 2.1 cells $/ \mu \mathrm{L}$, respectively (range $0-1.4$ in 1 study, not specified in the other) and in 129 term neonates $[14,16]$ it was
0.8 and 2.9 (range $0-65.0$ ) cells $/ \mu \mathrm{L}$. In term neonates, the CSF neutrophil count was higher in week 1 and 2 compared to week 3 and $4(p<0.05)$ [14]. The study which reported the value of 65 included the neonate with the WBC count of 130.0 cells/ $\mu \mathrm{L}$.

The two studies which reported individual neutrophil values are summarized in Table 2 and Figure $3[10,16]$. The mean neutrophil count was 5.0 cells/ $\mu \mathrm{L}$ in preterm neonates $(n=45)$ (SD 6.6, median 3.0, IQR 4.0, range $0-34.0)$ and 2.9 cells $/ \mu \mathrm{L}$ in term neonates $(n=21)$ (4.1, $2.0,4.0$, and $0-17.0)(p=0.04)$. The 95 th percentile for the CSF neutrophil count was 16.0 cells $/ \mu \mathrm{L}$ in preterm and 8.0 cells/ $\mu \mathrm{L}$ in term neonates.

\section{Protein Concentration}

Four studies (one in preterm neonates) investigated the protein concentration in CSF [10,13-15]. The protein concentration was higher in preterm $(n=53)$ compared with term neonates $(n=79)$ (mean $144.6 \mathrm{mg} / \mathrm{dL}$, range $52.0-300.0$ vs. mean $61.0-71.4 \mathrm{mg} / \mathrm{dL}$, range $8.0-140.0$ ). In term neonates, no difference was found between the protein concentration on day 2 and day 7 of life $(p=0.66)$ in one study [15], while another found a higher protein concentration in week 1 and 2 compared to week 3 and 4 $(p<0.05)$ [14]. In the study in preterm neonates, there was no correlation between the red blood cell (RBC) count and protein concentration; therefore, the observed increase in CSF protein cannot be attributed to a higher RBC count $(p=0.21)$ [10].

The two studies which reported individual values are summarized in Figure 4 [10,15]. The mean protein concentration was higher in preterm neonates $(n=53)$ (mean 144.6, SD 48.1, median 144.0, IQR 66.0, range 52.0-300.0) compared with term neonates $(n=79)(71.4,24.2,74.0$, 


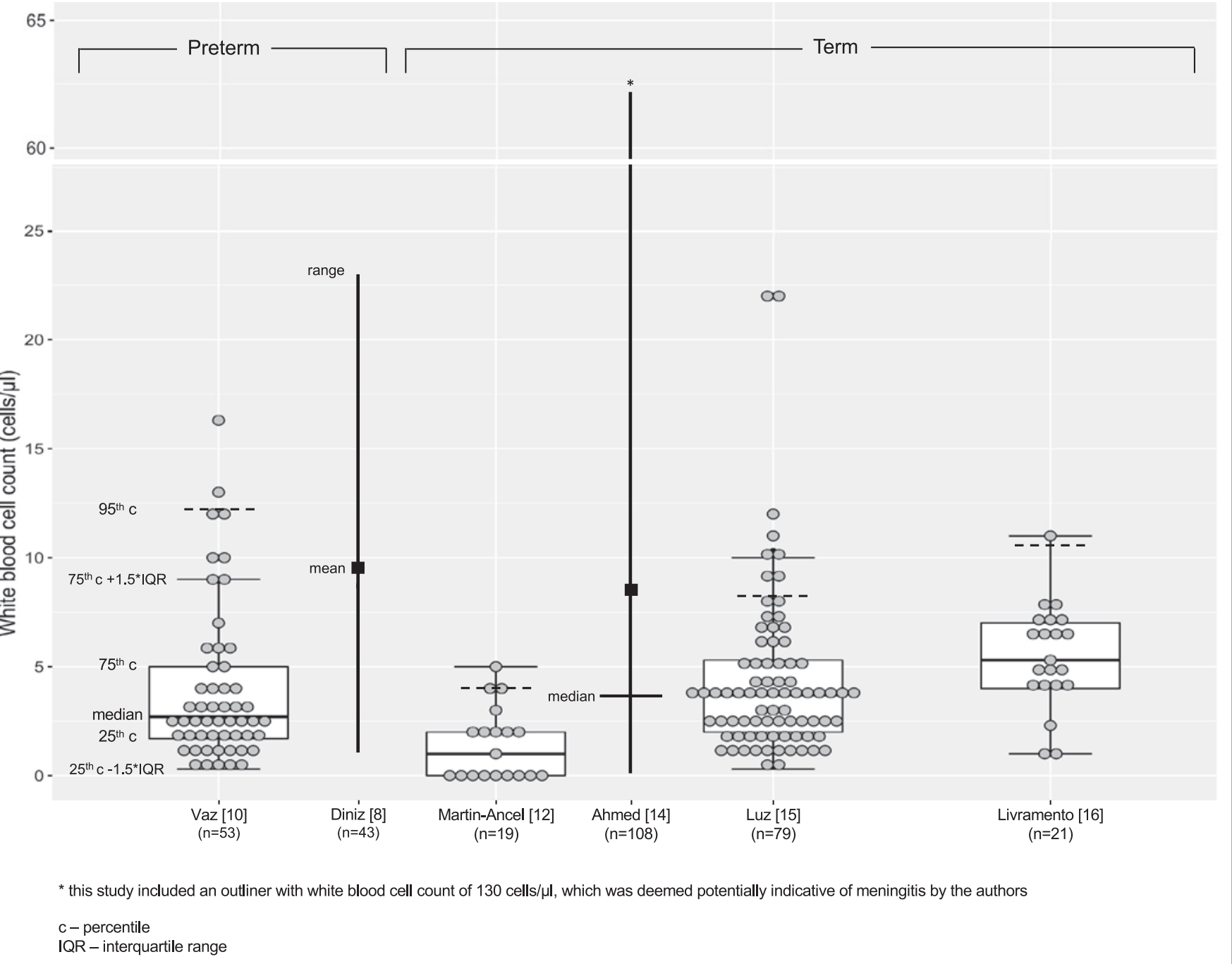

Fig. 2. The CSF WBC count in healthy preterm and term neonates. Boxplots show medians, interquartile ranges (IQR) with whiskers indicating 25 th percentile minus $1.5^{*} \mathrm{IQR}$ and 75 th percentile plus $1.5^{*} \mathrm{IQR}$, and dotted lines indicating the 95th percentile. For studies which did not report individual values, the range (solid vertical line), mean (square) and median (solid horizontal line) are shown.

35.5, and 19.0-140.0) $(p<0.01)$. The 95th percentile for CSF protein was $210.0 \mathrm{mg} / \mathrm{dL}$ in preterm and $110.2 \mathrm{mg} /$ $\mathrm{dL}$ in term neonates.

\section{Glucose Concentration}

Three studies (two in preterm neonates) reported glucose concentrations in CSF $[9,10,14]$. There was no difference in the mean glucose concentration between preterm $(57.5$ and $51.6 \mathrm{mg} / \mathrm{dL}$, range 35.0-162.0) and term neonates $(51.2 \mathrm{mg} / \mathrm{dL}$, range not specified). In term neonates, no difference was found between the glucose concentration between week 1-4 $(p>0.05)$ [14]. Only one study in 53 preterm neonates reported individual concentrations with a mean of $51.6 \mathrm{mg} / \mathrm{dL}, \mathrm{SD} 18.3$, median 49.0 , IQR 10.0, range 17.0-162.0) [10]. The 5th percentile for CSF glucose was $32.0 \mathrm{mg} / \mathrm{dL}$ (Table 2).

\section{Discussion}

The incidence of bacterial meningitis is highest in neonates, where it causes substantial morbidity and mortality. Despite an extensive literature review, we only found seven studies (reported in nine articles) investigating normal 


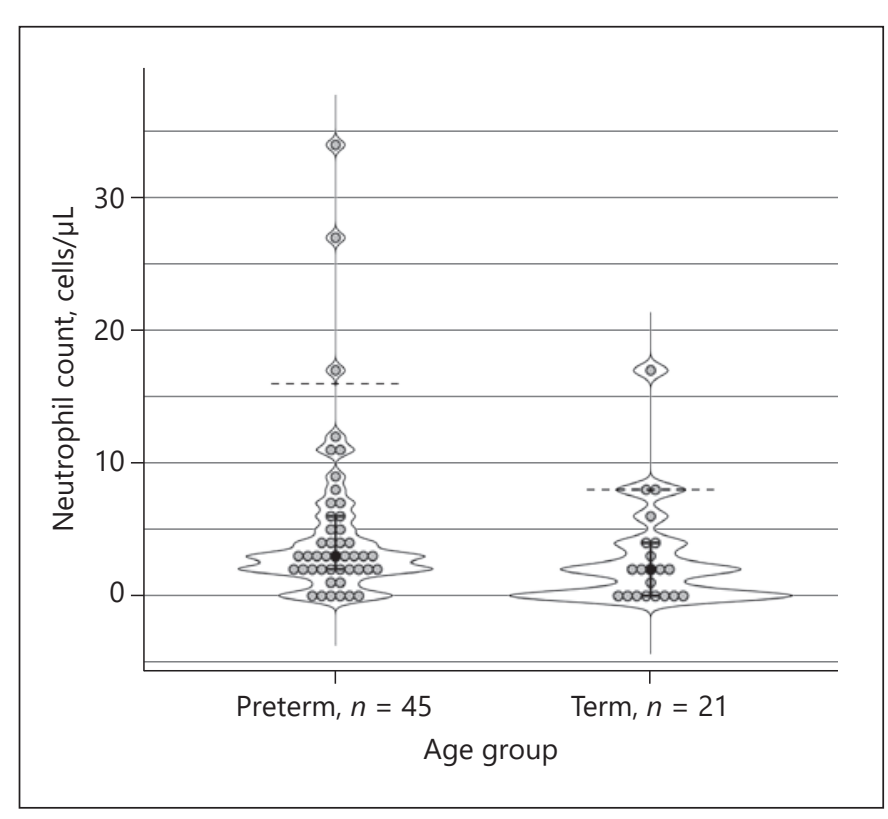

Fig. 3. The CSF neutrophil count in healthy preterm and term neonates showing the median (point), IQR (continuous line), and 95th percentile (dashed line). CSF, cerebrospinal fluid; IQR, interquartile range. Data shown only for the two studies which inlcuded individual values $[10,16]$.

CSF values that were of sufficient quality to be included in this systematic review. The main reason for exclusion of studies was the absence of viral diagnostics to exclude aseptic meningitis (see online suppl. Table 1; see www. karger.com/doi/10.1159/000517630 for all online suppl. material) [5-7, 17-38]. Even when viral culture is done, up to $35 \%$ of enteroviruses are not detected [39-42], and therefore polymerase chain reaction is necessary to reliably exclude viral meningitis. A further common exclusion reason was antibiotic administration before LP which can lead to false negative cultures and inclusion of neonates with meningitis $[3,4,43,44]$. The degree to which antibiotic administration changes CSF parameters is still unknown. One study found that protein concentrations were significantly higher in neonates who had received antibiotics before LP than those who had not (median 92 vs. $80 \mathrm{mg} / \mathrm{dL}, p=0.02$ ) but CSF WBC and glucose concentration did not differ between the two groups [3]. Comparing our findings with studies which included neonates who had received antibiotics before LP, the values for CSF glucose and protein concentrations (median and 95th percentile) and the median CSF WBC count in preterm and term infants were similar. However, the 95th percentile for CSF WBC was lower (12 vs. 16 cells/ $\mu \mathrm{L}$ in term infants and 9 vs. 12 cells/ $\mu \mathrm{L}$ in preterm term infants, respectively;

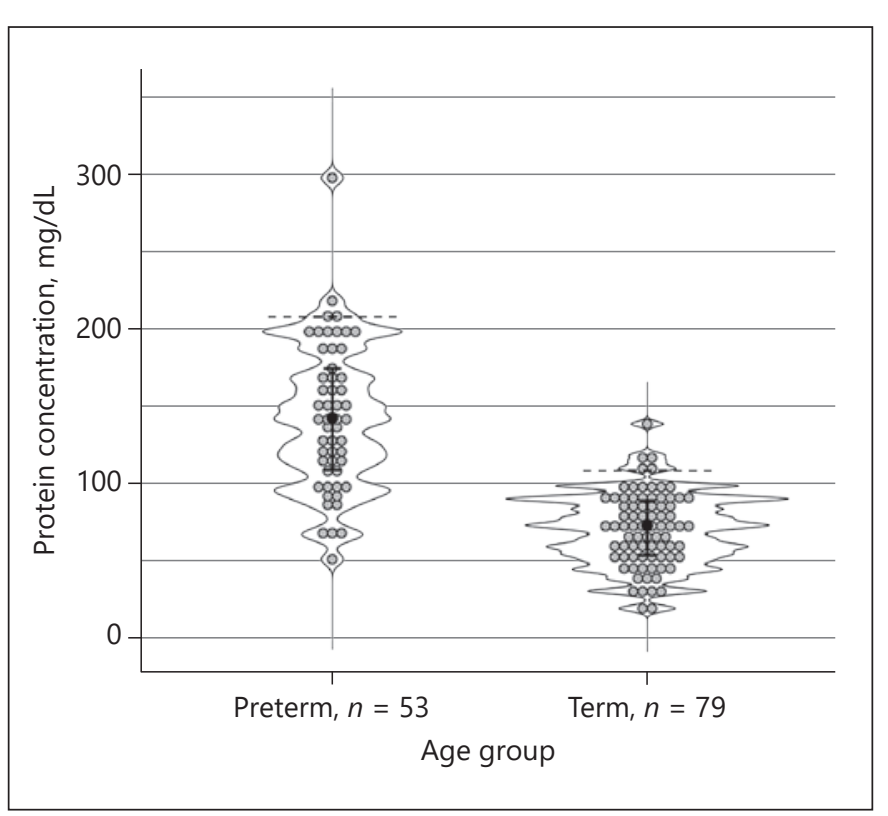

Fig. 4. Comparison between protein concentration in CSF in healthy preterm and term neonates showing the median (point), IQR (continuous line), and 95th percentile (dashed line). CSF, cerebrospinal fluid; IQR, interquartile range. Data shown only for the two studies which included individual values [10,15].

and 16 and 78 cells $/ \mu \mathrm{L}$ in the studies which did not specify separate values for preterm and term infants) $[3,43,44]$.

Many guidelines or reviews recommend a cutoff value of 20-22 CSF WBCs/ $\mu \mathrm{L}$ with a CSF neutrophil count of $<2-8$ cells/ $\mu \mathrm{L}$ for the diagnosis of meningitis in neonates [2, 45-47]. However, these recommendations are based on studies that included a proportion of patients who had been administered antibiotics before LP $[43,44]$ or which did not reliably exclude viral meningitis $[6,7,19,26,28]$. Consistent with this, a large study of neonatal meningitis including 9,111 neonates reported that a CSF WBC count of $>21$ cells $/ \mu \mathrm{L}$ has a sensitivity of $79 \%$ and specificity of $81 \%$ for bacterial meningitis [48] and another study, including 3,467 neonates, reported a 95th percentile of 16.0 cells/ $\mu \mathrm{L}$ and protein $118 \mathrm{mg} / \mathrm{dL}$ [43] (both studies did not meet the criteria for our review). In our review, we found that in $95 \%$ of cases, the CSF WBC count was $<12.0$ cells/ $\mu \mathrm{L}$ in preterm and $<9.2$ cells $/ \mu \mathrm{L}$ in term neonates, and the CSF neutrophil count $<16.0$ and 8.0 cells $/ \mu \mathrm{L}$, respectively. However, these values are derived from only the 4 studies for which individual patient data were reported. Even though it has previously been claimed that the presence of even a single polymorphonuclear leucocyte in CSF is pathological, the data from the studies included in our review suggests this might not be the case in neonates. 
CSF glucose and protein concentrations are highly variable in neonates $[6,7,43,48]$. However, a CSF protein concentration of $<150.0 \mathrm{mg} / \mathrm{dL}$ in preterm and $<100.0$ $\mathrm{mg} / \mathrm{dL}$ in term neonates, and a CSF glucose concentration of $>30.0-36.0 \mathrm{mg} / \mathrm{dL}$ is often considered as normal $[45,46]$. In our review, in $95 \%$ of cases the protein concentration was $<210.0 \mathrm{mg} / \mathrm{dL}$ in preterm neonates and $110.2 \mathrm{mg} / \mathrm{dL}$ in term neonates, respectively. In preterm neonates the 5th percentile for the CSF glucose concentration was $32.0 \mathrm{mg} / \mathrm{dL}$, while there were not enough individual data to determine percentiles for term neonates. These values are also only derived from only the 3 studies for which individual patient data were reported.

We found minimal difference in the CSF WBC count or glucose concentration between preterm and term neonates [8-12, 14-16]. However, the CSF neutrophil count and protein concentration were higher in preterm neonates than in term neonates $[8,10,11,13-16]$. Consistent with this, one of the studies done in term neonates which analysed consecutive samples reported that there was no difference in the WBC count and glucose concentration between the first and the fourth week of life, but the protein concentration was higher in the first than in the fourth week [14]. This is consistent with animal studies, which found increased concentration of growth factors and other proteins in the CSF of preterm compared to term animals [49]. However, it is often stated that this difference is due to increased permeability of the blood-brain barrier in preterm infants [50], this remains unproven. Animal studies suggest that the blood-CSF tight junctions are functionally mature from early life and that proteins are actively transferred transcellularly [51-53].

Even a small amount of blood or bilirubin in CSF can significantly alter the protein concentration $[54,55]$. In neonates, it has been estimated that $1,000 \mathrm{RBCs} / \mu \mathrm{L}$ raises the protein concentration by $1.5-1.9 \mathrm{mg} / \mathrm{dL}[56,57]$. However, in the study included in this review, there was no correlation between the RBC count and protein concentrations [10]; therefore, the observed increase in CSF protein is not attributable to a higher RBC count.

Unfortunately, none of the studies included in this review measured CSF lactate. Lactate is produced by anaerobic bacteria and not influenced by blood lactate concentration, which is an advantage compared to the CSF glucose concentration. A meta-analysis summarizing results from 30 studies in children and adults suggested that a CSF lactate concentration of $35 \mathrm{mg} / \mathrm{dL}$ could be used as a cutoff value to discriminate between viral and bacterial meningitis [58].
As we have previously shown, it is important to note that an initial CSF with a normal WBC count does not definitively exclude bacterial meningitis [59]. On the other hand, pleocytosis can be found in neonates without central nervous system infection, but with other infections, such as gastroenteritis [12] or urinary tract infections $[60,61]$.

The main limitation of our review is that there were only a small number of studies of sufficient quality to include. However, the use of stringent inclusion criteria means the normal neonatal CSF values determined in our review are likely to be more reliable. Another potential limitation is that not all the studies included in our review used molecular diagnostics to exclude viruses other than enterovirus (e.g., parechovirus or herpes virus) as a cause of neonatal meningitis and that some studies included neonates with a high $\mathrm{RBC}$ count. The paradoxical finding in preterm infants of a higher upper limit of normal for CSF neutrophils than for WBC cells $(16$ vs. $12 / \mu \mathrm{L})$ is a result of the small number of studies that provided differential CSF WBC counts. Furthermore, the small number of studies only enabled the influence of gestational age to be compared between preterm and term infants.

\section{Conclusion}

The interpretation of CSF in neonates can be challenging. The normal range for CSF parameters is different in neonates compared with older infants. Gestational and chronological age lead to only minor differences in CSF WBC and glucose concentrations, but have a greater influence on the CSF neutrophil count, RBC count, and protein concentration. CSF parameters alone are not sufficiently reliable to exclude meningitis. In clinical practice, CSF samples, regardless of cellularity and biochemistry, need to be subjected to culture and viral molecular diagnostics to reliably exclude meningitis.

\section{Statement of Ethics}

The paper is exempt from Ethical Committee approval as it is a review of previously published literature.

\section{Conflict of Interest Statement}

The authors declare no conflicts of interest. 


\section{Funding Sources}

The authors did not receive any funding.

\section{Author Contributions}

P.Z. drafted the initial manuscript. N.C. critically revised the manuscript and both authors approved the final manuscript as submitted.

\section{References}

1 Saunders NR, Dziegielewska KM, Møllgård K, Habgood MD: Physiology and molecular biology of barrier mechanisms in the fetal and neonatal brain. J Physiol 2018;596:5723-56.

2 Connell T, Curtis N. How to interpret a CSF: the art and the science. Adv Exp Med Biol. 2005;568:199-216.

3 Srinivasan L, Shah SS, Padula MA, Abbasi S, McGowan KL, Harris MC. Cerebrospinal fluid reference ranges in term and preterm infants in the neonatal intensive care unit. J Pediatr. 2012;161:729-34.

4 Shah SS, Ebberson J, Kestenbaum LA, Hodinka RL, Zorc JJ. Age-specific reference values for cerebrospinal fluid protein concentration in neonates and young infants. J Hosp Med. 2011;6:22-7.

5 Smith PB, Garges HP, Cotton CM, Walsh TJ, Clark RH, Benjamin DK Jr. Meningitis in preterm neonates: importance of cerebrospinal fluid parameters. Am J Perinatol. 2008;25:421-6.

6 Chadwick SL, Wilson JW, Levin JE, Martin JM. Cerebrospinal fluid characteristics of infants who present to the emergency department with fever: establishing normal values by week of age. Pediatr Infect Dis J. 2011;30:e63-7.

7 Byington CL, Kendrick J, Sheng X. Normative cerebrospinal fluid profiles in febrile infants. J Pediatr. 2011;158:130-4.

8 Diniz EM, Netto AS, Livramento JA, Machado LR, Castilho EA, Corradini HB, et al. [Cerebrospinal fluid of premature newborn infants during the neonatal period. II. Cytomorphological study]. Bol Med Hosp Infant Mex. 1982;39:409-12.

9 de Albuquerque Diniz EM, Spina-França Netto A, Livramento JA, Machado LR, Ayres Castilho E, Bahía Corradini H, et al. [Cerebrospinal fluid in premature newborn infants during the neonatal period. I. Biochemical aspects]. Bol Med Hosp Infant Mex. 1982;39: 253-7.

10 Vaz FA, Livramento JA, Spina-França A. [Cerebrospinal fluid in the healthy preterm newborn infant]. Arq Neuropsiquiatr. 1977;35:183-8.

11 Vaz Flavio AC, Livramento JA, Spina-França A. [Composition of the cerebrospinal fluid in the premature newborn infant]. Bol Med Hosp Infant Mex. 1977;34:1135-46.

12 Martin-Ancel A, Garcia-Alix A, Salas S, Del Castillo F, Cabanas F, Quero J. Cerebrospinal fluid leucocyte counts in healthy neonates. Arch Dis Child Fetal Neonatal Ed. 2006;91: F357-358.

13 Wong M, Schlaggar BL, Buller RS, Storch GA, Landt M. Cerebrospinal fluid protein concentration in pediatric patients: defining clini- cally relevant reference values. Arch Pediatr Adolesc Med. 2000;154:827-31.

14 Ahmed A, Hickey SM, Ehrett S, Trujillo M, Brito F, Goto C, et al. Cerebrospinal fluid values in the term neonate. Pediatr Infect Dis J. 1996;15:298-303.

15 Luz BR. [Composition of the cerebrospinal fluid in the normal newborn infant. Cytology, proteins and bilirubin in 79 samples of cerebrospinal fluids]. Arq Neuropsiquiatr. 1975; 33:200-9.

16 Livramento JA, da Luz BR, Haussen SR, Spina-França A. [Cytomorphology of the cerebrospinal fluid in the normal newborn infant]. Arq Neuropsiquiatr. 1974;32:207-11.

17 Tarvij Eslami S, Nassirian H, Mojgan BM, Bahieh ZZ, Elham H, Alimohamad N, et al. Comparison of cerebrospinal fluid in newborns and in infants $\leq 2$ months old with or without meningitis. Pediatr Int. 2012;54:336-40.

18 Mhanna MJ, Alesseh H, Gori A, Aziz HF. Cerebrospinal fluid values in very low birth weight infants with suspected sepsis at different ages. Pediatr Crit Care Med. 2008;9:294-8.

19 Rodriguez AF, Kaplan SL, Mason EO Jr. Cerebrospinal fluid values in the very low birth weight infant. J Pediatr. 1990;116:971-4.

20 Bonadio WA. Bacterial meningitis in children whose cerebrospinal fluid contains polymorphonuclear leukocytes without pleocytosis. Clin Pediatr. 1988;27:198-200.

21 Pappu LD, Purohit DM, Levkoff AH, Kaplan B. CSF cytology in the neonate. Am J Dis Child. 1982;136:297-8.

22 Illi OE, Kaiser G, Weber RM, Spengler GA. CSF protein values in infants and children. Helv Paediatr Acta. 1983;38:323-7.

23 Gill GV, Benson JB. Cerebrospinal fluid findings in African pre-term infants. Cent Afr J Med. 1980;26:182-3.

24 Heine W, Hobusch D, Drescher U. [Cerebrospinal fluid protein levels and blood-cerebrospinal fluid ratio of glucose and electrolytes in infants and children]. Helv Paediatr Acta. 1981;36:217-27.

25 Jasso Gutiérrez L, Cuevas Izaguirre J. [Characteristics of the spinal fluid in the neonatal stage]. Bol Med Hosp Infant Mex. 1977;34: 536-42.

26 Sarff LD, Platt LH, McCracken GH Jr. Cerebrospinal fluid evaluation in neonates: comparison of high-risk infants with and without meningitis. J Pediatr. 1976;88:473-7.

27 Krause HD, Wisser $\mathrm{H}$. [The normal range for total protein and protein fractions in the cerebrospinal fluid of children (author's transl)]. Z Klin Chem Klin Biochem. 1975;13:137-42.
28 Naidoo BT. The cerebrospinal fluid in the healthy newborn infant. S Afr Med J. 1968;42: 933-5.

29 Roldán EJ, Castroviejo IP, Coviella LG, Rodríguez-Lecumberri JG, Prados ER. [The cerebrospinal fluid in normal premature infants]. Rev Port Pediatr Pueric. 1968;31:219-31.

30 Otila E. Studies on the cerebrospinal fluid in premature neonates. Acta Paediatr. 1949;35.

31 Bonadio WA, Stanco L, Bruce R, Barry D, Smith D. Reference values of normal cerebrospinal fluid composition in infants ages 0 to 8 weeks. Pediatr Infect Dis J. 1992;11:589-91.

32 Bonadio WA, Smith DS. CBC differential profile in distinguishing etiology of neonatal meningitis. Pediatr Emerg Care. 1989;5:94-6.

33 Portnoy JM, Olson LC. Normal cerebrospinal fluid values in children: another look. Pediatrics. 1985;75:484-7.

34 Escobedo M, Barton L, Volpe J. Cerebrospinal fluid studies in an intensive care nursery. J Perinat Med. 1975;3:204-10.

35 de Blauw D, Bruning A, Vijn LJ, Wildenbeest JG, Wolthers KC, Biezeveld MH, et al. Blood and cerebrospinal fluid characteristics in neonates with a suspected central nervous system infection. Medicine. 2019;98:e16079.

36 Liu Z, Jia D, Dai J, Zhou X, Qin Z, Chen L, et al. Age-specific reference values for cerebrospinal fluid protein concentrations in children in southern China. Medicine. 2019;98: e17500.

37 Majumdar A, Jana A, Jana A, Biswas S, Bhatacharyya S, Bannerjee S. Importance of normal values of CSF parameters in term versus preterm neonates. J Clin Neonatol. 2013; 2:166-8.

38 Moreno-Carvalho OA, Cardoso MR, Nascimento-Carvalho CM. Neutrophils and red blood cells in the cerebrospinal fluid of newborns. Acta Paediatr. 2008;97:816-8.

39 Hosoya M, Sato M, Honzumi K, Katayose M, Sakuma H, Ishiko H, et al. Application of polymerase chain reaction and subsequent phylogenetic analysis to the diagnosis of enteroviral infection in the central nervous system. J Clin Virol. 2002;25(Suppl 1):S2738.

40 Palacios Poggio G, Cisterna D, Freire MC, Cello J. RT-nested PCR for the detection of enterovirus in biological samples from patients with suspected enteroviral infections. Rev Argent Microbiol. 2000;32:165-72.

41 Shaker OG, Abdelhamid N. Detection of enteroviruses in pediatric patients with aseptic meningitis. Clin Neurol Neurosurg. 2015; 129:67-71. 
42 Schlesinger Y, Sawyer MH, Storch GA. Enteroviral meningitis in infancy: potential role for polymerase chain reaction in patient management. Pediatrics. 1994;94:157-62.

43 Thomson J, Sucharew H, Cruz AT, Nigrovic LE, Freedman SB, Garro AC, et al. Cerebrospinal fluid reference values for young infants undergoing lumbar puncture. Pediatrics. 2018;141:e20173405.

44 Kestenbaum LA, Ebberson J, Zorc JJ, Hodinka RL, Shah SS. Defining cerebrospinal fluid white blood cell count reference values in neonates and young infants. Pediatrics. 2010; 125:257-64.

45 The Royal Children's Hospital Melbourne. CSF interpretation. 2019. Available from: https: //www.rch.org.au/clinicalguide/guideline_index/csf/.

46 Edwards MS, Baker CJ. Bacterial meningitis in the neonate: clinical features and diagnosis. 2018. Available from: https://www.uptodate. $\mathrm{com} /$ contents/bacterial-meningitis-in-the-neonate-clinical-features-and-diagnosis\#H12.

47 National Institute for Health and Care Excellence. 2018 surveillance of meningitis (bacterial) and meningococcal septicaemia in under 16s: recognition, diagnosis and management (NICE guideline CG102). London, UK: Copyright @ NICE 2018; 2018.
48 Garges HP, Moody MA, Cotten CM, Smith PB, Tiffany KF, Lenfestey R, et al. Neonatal meningitis: what is the correlation among cerebrospinal fluid cultures, blood cultures, and cerebrospinal fluid parameters? Pediatrics. 2006;117:1094-100.

49 Johansson PA, Dziegielewska KM, Liddelow SA, Saunders NR. The blood-CSF barrier explained: when development is not immaturity. Bioessays. 2008;30:237-48.

50 Statz A, Felgenhauer K. Development of the blood-CSF barrier. Dev Med Child Neurol. 1983;25:152-61.

51 Ek CJ, Habgood MD, Dziegielewska KM, Potter A, Saunders NR. Permeability and route of entry for lipid-insoluble molecules across brain barriers in developing Monodelphis domestica. J Physiol. 2001;536:841-53.

52 Johansson PA, Dziegielewska KM, Ek CJ, Habgood MD, Liddelow SA, Potter AM, et al. Blood-CSF barrier function in the rat embryo. Eur J Neurosci. 2006;24:65-76.

53 Tauc M, Vignon X, Bouchaud C. Evidence for the effectiveness of the blood: CSF barrier in the fetal rat choroid plexus. A freeze-fracture and peroxidase diffusion study. Tissue Cell. 1984;16:65-74.

54 Palazzi DL, Klein JO, Baker CJ. Bacterial sepsis and meningitis. In: Remington JSK, Jerome O, Wilson CB, Baker CJ, editors. Infectious diseases of the fetus and newborn infant. Philadelphia, PA: Elsevier, Inc.; 2006. p. 247-95.
55 National Committee for Clinical Laboratory Standards. Interference testing in clinical chemistry. Wayne, PA: NCCLS; 1986. Document EP7.

56 Srinivasan L, Shah SS, Abbasi S, Padula MA, Harris MC. Traumatic lumbar punctures in infants hospitalized in the neonatal intensive care unit. Pediatr Infect Dis J. 2013;32:11502.

57 Hines EM, Nigrovic LE, Neuman MI, Shah SS. Adjustment of cerebrospinal fluid protein for red blood cells in neonates and young infants. J Hosp Med. 2012;7:325-8.

58 Sakushima K, Hayashino Y, Kawaguchi T, Jackson JL, Fukuhara S. Diagnostic accuracy of cerebrospinal fluid lactate for differentiating bacterial meningitis from aseptic meningitis: a meta-analysis. J Infect. 2011;62:25562.

59 Zimmermann P, Curtis N. Bacterial meningitis in the absence of pleocytosis in children: a systematic review. Pediatr Infect Dis J. 2021; 40(6):582-7.

60 Shah SS, Zorc JJ, Levine DA, Platt SL, Kuppermann N. Sterile cerebrospinal fluid pleocytosis in young infants with urinary tract infections. J Pediatr. 2008;153:290-2.

61 Syrogiannopoulos GA, Grivea IN, Anastassiou ED, Triga MG, Dimitracopoulos GO, Beratis NG. Sterile cerebrospinal fluid pleocytosis in young infants with urinary tract infection. Pediatr Infect Dis J. 2001;20:927-30 